\title{
Anaerobic Digestion untuk Pengolahan Sampah Organik: Analisis Multikriteria Menggunakan Metode Analytic Network Process
}

\author{
Mochammad Chaerul ${ }^{1, *}$, Yahdini Qornin Mardiyah ${ }^{2}$ \\ ${ }^{1,2}$ Departemen Teknik Lingkungan, Fakultas Teknik Sipil dan Lingkungan, \\ Institut Teknologi Bandung \\ *Koresponden email: m.chaerul@ftsl.itb.ac.id
}

Diterima: 9 Mei 2019

Disetujui: 2 Juli 2019

\begin{abstract}
Organic waste can be treated through anaerobic digestion in a bioplant facility. Different management pattern of bioplant has different consequences to each criterion affecting the sustainability of the bioplant. The study aims to apply multicriteria analysis using Analytic Network Process (ANP) method to alternatives of the bioplant management available in Bandung City as a case study. Multicriteria developed in the study, namely Technical, Environment, Social, and Economic, have their respective subcriterions to be analyzed further through interview to related stakeholders. The result revealed that the following subcriterions had the highest driving power and dependency: construction and operational, pretreatment, and availability of infrastructure (Technical criterion), amount of labor required, readiness of community for waste segregation (Social), and investment and operational costs (Economic). All subcriterions in criterion of Environment were deemed not so important. The best alternative choosen was a bioplant with waste segregation by generator at source and supported with waste bank.
\end{abstract}

Keywords: organic waste, anaerobic digestion, bioplant, multicriteria analysis, analytic network process, stakeholders

\begin{abstract}
Abstrak
Sampah organik dapat diolah menggunakan proses anaerobic digestion dalam suatu fasilitas bioplant. Pola pengelolaan bioplant memiliki konsekuensi berbeda untuk tiap kriteria yang dapat mempengaruhi keberbelanjutan bioplant. Penelitian ini bertujuan untuk mengaplikasikan analisis multikriteria dengan metode Analytic Network Process (ANP) terhadap alternatif pengelolaan bioplant di Kota Bandung sebagai studi kasusnya. Empat kriteria yang dikembangkan terdiri dari: Teknis, Lingkungan, Sosial dan Ekonomi, yang masing-masing memiliki subkriteria untuk dianalisis lebih lanjut melalui wawancara kepada stakeholder terkait. Hasil penelitian menunjukkan bahwa subkriteria dari setiap kriteria yang memiliki driving power dan dependency tinggi adalah konstruksi dan operasional, pretreatment, dan ketersediaan prasarana sarana (Teknis), penyerapan tenaga kerja, dan kesiapan masyarakat untuk memilah sampah (Sosial), serta biaya investasi, dan biaya operasional (Ekonomi). Semua subkriteria di kriteria lingkungan dinilai tidak terlalu berpengaruh. Dari tiga alternatif yang dikembangkan, alternatif yang dinilai terbaik adalah fasilitas bioplant yang didukung adanya pemilahan sampah mulai di sumber dan bank sampah.
\end{abstract}

Kata Kunci: sampah organik, anaerobic digestion, bioplant, analisis multikriteria, analytic network process, stakeholder

\section{Pendahuluan}

Pengelolaan sampah merupakan salah satu isu lingkungan penting yang dihadapi oleh berbagai kota di negara berkembang seperti Indonesia, termasuk di Kota Bandung. Jika pengelolaan sampah tidak ditangani dengan baik, secara langsung maupun tidak langsung akan berdampak terhadap lingkungan, kesehatan masyarakat, dan berpotensi menimbulkan permasalahan lainnya (Liao dan Chiu, 2011). Seiring peningkatan populasi, jumlah sampah yang dihasilkan pun semakin meningkat, sehingga perlu dikembangkan sistem pengelolaan sampah yang lebih baik (Aziz dkk., 2019).

Pendekatan pengelolaan sampah yang digunakan saat ini di Indonesia adalah end of pipe yaitu penanganan limbah yang dilakukan setelah limbah terbentuk. Dengan pendekatan tersebut, sebagian besar sampah diolah dengan cara penimbunan (landfilling) di Tempat Pemrosesan Akhir (TPA). Konsep end of pipe perlu diperbaiki melalui kegiatan minimasi atau 
Tabel 1. Resume kondisi eksisting fasilitas bioplant yang diobservasi

\begin{tabular}{|c|c|c|c|c|}
\hline \multirow{2}{*}{ Parameter } & \multicolumn{4}{|c|}{ Lokasi Bioplant (Kelurahan) } \\
\hline & Babakan Sari & Merdeka & Cipadung & Cibangkong \\
\hline Sumber sampah & $\begin{array}{l}\text { Rumah tangga, } \\
\text { pasar }\end{array}$ & $\begin{array}{l}\text { Rumah tangga, } \\
\text { rumah makan }\end{array}$ & Rumah tangga & Rumah tangga \\
\hline $\begin{array}{l}\text { Jenis sampah yang masuk ke } \\
\text { fasilitas }\end{array}$ & $\begin{array}{l}\text { Organik, } \\
\text { anorganik }\end{array}$ & $\begin{array}{l}\text { Organik, } \\
\text { anorganik }\end{array}$ & Organik & Organik \\
\hline $\begin{array}{l}\text { Jenis sampah organik yang } \\
\text { masuk ke fasilitas }\end{array}$ & $\begin{array}{l}\text { Sisa makanan, } \\
\text { sisa sayuran dan } \\
\text { buah-buahan }\end{array}$ & $\begin{array}{l}\text { Sisa makanan, } \\
\text { sisa sayuran dan } \\
\text { buah-buahan }\end{array}$ & $\begin{array}{l}\text { Sisa makanan, } \\
\text { sisa sayuran dan } \\
\text { buah-buahan }\end{array}$ & $\begin{array}{l}\text { Sisa makanan, } \\
\text { sisa sayuran dan } \\
\text { buah-buahan }\end{array}$ \\
\hline Jumlah sampah organik & $50 \mathrm{~kg} / \mathrm{hari}$ & $200 \mathrm{~kg} /$ dua hari & $20-25 \mathrm{~kg} / \mathrm{hari}$ & 7-10 kg/hari \\
\hline Kapasitas pengolahan & $250 \mathrm{~kg} / \mathrm{hari}$ & $250 \mathrm{~kg} / \mathrm{hari}$ & $250 \mathrm{~kg} / \mathrm{hari}$ & 20 kg/hari \\
\hline Pemilahan sampah di sumber & $\mathrm{Ya}$ & $\mathrm{Ya}$ & $\mathrm{Ya}$ & Ya \\
\hline Pelaku pengumpulan sampah & Penghasil sampah & $\begin{array}{l}\text { Petugas } \\
\text { Kelurahan }\end{array}$ & $\begin{array}{l}\text { Petugas } \\
\text { Kelurahan }\end{array}$ & Penghasil sampah \\
\hline Pemilahan sampah di fasilitas & Tidak & Ya & Tidak & Tidak \\
\hline Bank sampah & Ada & Tidak ada & Tidak ada & Tidak ada \\
\hline Pretreatment sampah organik & Tidak ada & Tidak ada & Tidak ada & Tidak ada \\
\hline Penggunaan biogas & Internal & Internal & Internal & Internal \\
\hline Penggunaan cairan & $\begin{array}{c}\text { Internal } \\
\text { (penyiraman } \\
\text { kompos) }\end{array}$ & Tidak ada & $\begin{array}{l}\text { Internal } \\
\text { (pupuk } \\
\text { tanaman) }\end{array}$ & $\begin{array}{c}\text { Internal } \\
\text { (pupuk tanaman) }\end{array}$ \\
\hline
\end{tabular}

pengurangan sampah yang perlu ditangani (Nizar dkk, 2017). Minimasi sampah dilakukan melalui pendekatan 3R dengan cara penggunaan kembali (reuse), pemanfaatan kembali limbah secara langsung (reuse) dan/atau melalui sebuah proses pemanfaatan (recycle) terhadap sampah tersebut.

Kota Bandung menghasilkan sampah sebesar 1.757 ton/hari dengan sumber timbulan sampah yang dominan adalah berasal dari pemukiman/ rumah tangga yaitu sebesar 909,15 ton/hari (Helmy $d k k$., 2006). Sampah dari rumah tangga didominasi sampah organik yang mudah terdegradasi melalui proses biologi yang melibatkan mikroorganisme. Di
Bandung sedang dikembangkan pengelolaan sampah dengan sistem desentralisasi dimana persoalan sampah diharapkan dapat diselesaikan di sumbernya dengan memfokuskan pada pemanfaatan kembali material dan energi dari sampah melalui kegiatan daur ulang, diantaranya melalui aplikasi Anaerobic Digestion (AD) untuk pengolahan sampah organiknya.

Anaerobic digestion merupakan proses degradasi biomassa organik pada kondisi tanpa oksigen. Sampah organik dari rumah tangga berpotensimenjadi biomassa untuk diolah menggunakan suatu reaktor (yang disebut biodigester) karena mengandung substrat yang mudah didegradasi oleh mikroorganisme. Pengolahan

Tabel 2. Kriteria dan subkriteria terpilih dalam penelitian

\begin{tabular}{lcl}
\hline \multirow{2}{*}{ Kriteria } & \multicolumn{1}{c}{ Subkriteria } \\
\cline { 2 - 3 } Teknis (T) & Kode & \multicolumn{1}{c}{ Uraian } \\
& T1 & Penanganan awal terhadap sampah \\
& T2 & Konstruksi dan operasional \\
& T3 & Ketersediaan sarana dan prasarana \\
Lingkungan (L) & T4 & Luas lahan dibutuhkan \\
& L1 & Potensi timbulnya bau \\
& L2 & Potensi berkembangnya vektor penyakit \\
& L3 & Potensi gangguan estetika \\
Sosial (S) & L4 & Potensi pencemaran udara \\
& S1 & Penyerapan tenaga kerja \\
& S2 & Kesiapan masyarakat untuk memilah sampah \\
& S3 & Lapangan usaha \\
Ekonomi (E) & S4 & Kesesuaian dengan budaya masyarakat \\
& E1 & Biaya investasi (E1) \\
& E2 & Biaya operasional (E2) \\
& E3 & Kesejahteraan masyarakat (E3) \\
& E4 & Keuntungan finansial (E4)
\end{tabular}


Alternatif 1:

\begin{tabular}{|c|c|c|c|}
\hline $\begin{array}{l}\text { Pemilahan di } \\
\text { sumber }\end{array}$ & $\begin{array}{l}\text { Pengumpulan } \\
\text { oleh petugas }\end{array}$ & $\begin{array}{l}\text { Tidak ada pemilahan } \\
\text { di fasilitas }\end{array}$ & $\begin{array}{l}\text { Penggunaan produk untuk } \\
\text { internal dan eksternal }\end{array}$ \\
\hline
\end{tabular}

Alternatif 2:

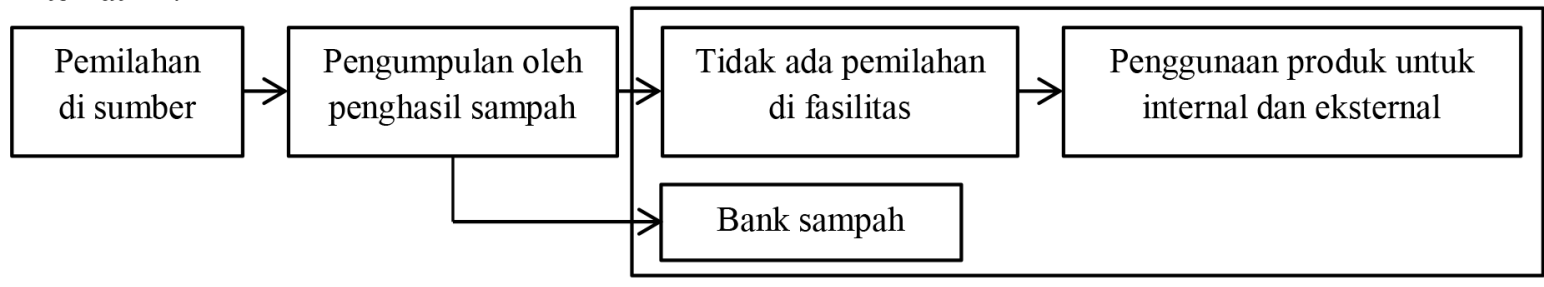

Alternatif 3:

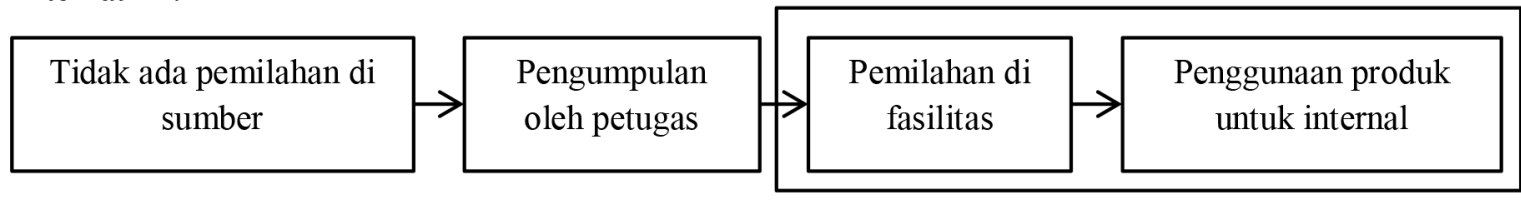

Gambar 1. Alternatif sistem pengelolaan fasilitas biodigester

sampah organik menggunakan anaerobic digestion merupakan proses yang bersifat berkelanjutan dan berpotensi menguntungkan karena selain mereduksi sampah organik, dalam proses ini dihasilkan biogas yang berenergi tinggi dan digestate yang dapat digunakan sebagai zat aditif bagi tanah (Jingura dan Matengaifa, 2009). Biodigester merupakan unit pengolahan utama dalam suatu fasilitas bioplant.

Pengelolaan sampah yang berkelanjutan, termasuk untuk operasional AD tidak hanya meliputi permasalahan sosial, namun penggabungan dari kriteria politik, kultur sosial, teknis, keuangan, dan lingkungan. Oleh karena itu dalam merumuskan dan mengimplementasikan strategi pengelolaan sampah padat, stakeholder perlu memperhatikan berbagai macam kriteria (Khan dan Faisal, 2008). Analisis multikriteria merupakan metode pengambilan keputusan yang membandingkan alternatif menggunakan beberapa kriteria secara serempak pada kondisi yang kompleks (Bottero $d k k$., 2011). Kriteria yang dipertimbangkan dalam pengambilan keputusan seringkali memiliki keterkaitan satu sama lain, sehingga metode Analytic Network Process (ANP) dapat digunakan untuk memodelkan permasalahan dengan keterkaitan antar kriteria (Aragones-Beltran $d k k$., 2011). ANP merupakan teknik pengambilan keputusan komprehensifyang mampu menggabungkan semua kriteria relevan dimana terdapat beberapa hubungan untuk menuju suatu keputusan (Kasirian $d k k ., 2010)$. Metode ANP telah banyak digunakan di berbagai macam bidang penelitian, termasuk juga di bidang pengelolaan sampah (Tseng, 2009, MolinosSenante $d k k$., 2015, Coban $d k k$., 2018, Arikan $d k k$., 2017, Gitinavard $d k k$., 2017).

Penelitian ini bertujuan untuk mengaplikasikan analisis multikriteria menggunakan metode ANP terhadap alternatif pengelolaan fasilitas bioplant dengan mengambil studi kasus di Kota Bandung dengan melibatkan penilaian dari berbagai macam stakeholder terkait. Dengan adanya pemilihan alternatif yang mempertimbangkan berbagai macam kriteria maka diharapkan keberadaan suatu fasilitas bioplant dapat beroperasi secara berkelanjutan dalam mendukung suatu sistem pengelolaan sampah suatu kota.

\section{Metodologi}

\subsection{Evaluasi Kondisi Eksisting Fasilitas Bioplant}

Di kota Bandung telah dipasang beberapa fasilitas bioplant. Pada penelitian ini dipilih empat fasilitas yang masih beroperasi dan sumber sampah umpannya berasal dari rumah tangga. Lokasi terpilih adalah fasilitas bioplant di Kelurahan Babakan Sari, Kelurahan Merdeka, Kelurahan Cipadung dan Kelurahan Cibangkong. Kondisi eksisting fasilitas bioplant diidentifikasi berdasarkan observasi, pengumpulan data sekunder dan wawancara. Data hasil identifikasi kondisi eksisting selanjutnya dianalisis dan dievaluasi secara komprehensif.

\subsection{Penentuan Kriteria, Subkriteria dan Alternatif}

Kriteria, subkriteria dan alternatif dirumuskan 
Tabel 3. Hubungan ketergantungan antar kriteria

\begin{tabular}{|c|c|c|c|c|c|c|c|c|c|c|c|c|c|c|c|c|c|c|}
\hline \multirow{2}{*}{ Kriteria } & \multirow{2}{*}{$\begin{array}{c}\text { Sub- } \\
\text { kriteria }\end{array}$} & \multicolumn{4}{|c|}{ Teknis } & \multicolumn{4}{|c|}{ Lingkungan } & \multicolumn{4}{|c|}{ Sosial } & \multicolumn{4}{|c|}{ Ekonomi } & \multirow{2}{*}{$\begin{array}{c}\text { Driving } \\
\text { Power }\end{array}$} \\
\hline & & $\mathrm{Tl}$ & $\mathrm{T} 2$ & T3 & T4 & $\mathrm{Ll}$ & $\mathrm{L} 2$ & L3 & L4 & Sl & $\mathrm{S} 2$ & S3 & S4 & El & E2 & E3 & E4 & \\
\hline Teknis & T1 & & 1 & 1 & 1 & & & 1 & 1 & 1 & & & & 1 & 1 & & & 8 \\
\hline \multirow[t]{3}{*}{$(\mathrm{T})$} & $\mathrm{T} 2$ & 1 & & 1 & & & & & & & 1 & & & 1 & 1 & & & 5 \\
\hline & T3 & 1 & 1 & & & & & 1 & & 1 & 1 & & & 1 & 1 & & & 7 \\
\hline & T4 & 1 & & 1 & & & & & & & & & & 1 & 1 & & & 4 \\
\hline Ling- & L1 & 1 & & & & & & & & & 1 & & & & & & & 2 \\
\hline \multirow{2}{*}{$\begin{array}{l}\text { kungan } \\
\text { (L) }\end{array}$} & L2 & & 1 & & & 1 & & & & & & & & & & & & 2 \\
\hline & $\begin{array}{l}\text { L3 } \\
\text { L4 }\end{array}$ & 1 & 1 & 1 & & & & & & & 1 & & & & & & & $\begin{array}{l}4 \\
0\end{array}$ \\
\hline \multirow{4}{*}{$\begin{array}{l}\text { Sosial } \\
\text { (S) }\end{array}$} & $\mathrm{S} 1$ & 1 & 1 & 1 & & & & & & & 1 & 1 & & 1 & 1 & & & 7 \\
\hline & S2 & 1 & 1 & 1 & & 1 & & 1 & & 1 & & 1 & 1 & 1 & 1 & & 1 & 11 \\
\hline & S3 & & & & & 1 & & 1 & & 1 & 1 & & & 1 & 1 & 1 & 1 & 8 \\
\hline & S4 & & 1 & 1 & & & & & & & 1 & & & & & 1 & & 4 \\
\hline \multirow{4}{*}{$\begin{array}{l}\text { Ekono- } \\
\text { mi (E) }\end{array}$} & El & 1 & & 1 & 1 & & & & 1 & & & & & & 1 & & & 5 \\
\hline & E2 & 1 & 1 & 1 & & & & & & 1 & & & & 1 & & 1 & 1 & 7 \\
\hline & E3 & & & & & & & & & & & 1 & & & & & 1 & 2 \\
\hline & E4 & & & & & & & & & & & & & 1 & & 1 & & 2 \\
\hline \multicolumn{2}{|c|}{$\begin{array}{l}\text { Dependence } \\
\text { Power }\end{array}$} & 9 & 8 & 9 & 2 & 3 & 0 & 4 & 2 & 5 & 7 & 3 & 1 & 9 & 8 & 4 & 4 & \\
\hline
\end{tabular}

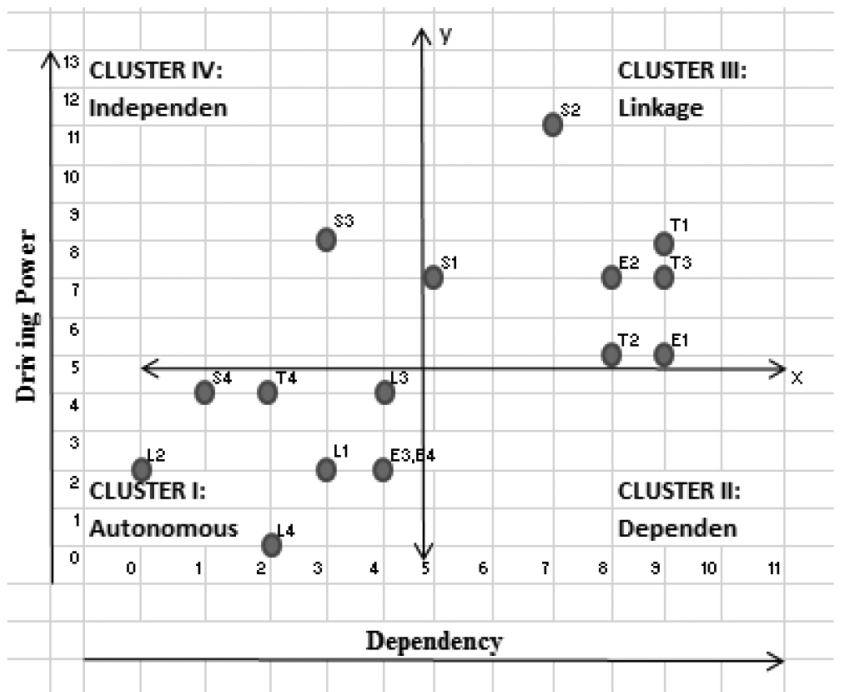

Gambar 2. Pemetaan subkriteria berdasarkan dependency dan driving power

berdasarkan studi literatur, penelitian terdahulu, serta pertimbangan kondisi eksisting. Usulan kriteria dan subkriteria diajukan kepada stakeholder untuk dipilih mana yang benar-benar relevan dalam implementasi fasilitas bioplant. Stakeholder dapat menambahkan kriteria atau subkriteria penting lain yang belum tercantum. Kriteria dan subkriteria yang memiliki pemilih terbanyak selanjutnya dipilih menjadi kriteria dan subkriteria yang digunakan dalam penelitian. Beberapa alternatif disusun berdasarkan evaluasi kondisi eksisting, lalu dikonfirmasikan kepada stakeholder mengenai kelayakan alternatif tersebut untuk diimplementasikan. Stakeholder yang dipilih terdiri mewakili pemerintah (2 orang), pengelola bioplant (2 orang), dan masyarakat dalam wilayah studi (6 orang).

\subsection{Penentuan Hubungan Keterkaitan Antar Subkriteria}

Responden untuk menentukan hubungan keterkaitan antar subkriteria terdiri atas pemerintah (7 orang), pengelola bioplant (8 orang), masyarakat (11 orang) dan akademisi (5 orang). Karena jumlah reponden untuk penilaian hubungan keterkaitan antar subkriteria adalah sebanyak 31 responden, sehingga apabila terdapat lebih dari atau sama dengan setengah dari total responden (yaitu sebanyak 16 responden) yang menilai terdapat pengaruh pada subkriteria, maka terdapat hubungan keterkaitan antara subkriteria tersebut. Oleh karena itu, nilai pada interfactorial 
dominance matrix adalah 1. Apabila jumlah responden yang memilih kurang dari 16, maka nilai pada matriks adalah 0 .

Penentuan hubungan keterkaitan akan menggunakan metode Dependence and Driving Power Analytic (DDPA). Nilai kekuatan penggerak (driving power) dan ketergantungan (dependent) dari setiap subkriteria ditentukan melalui interfactorial dominance matrix. Semakin tinggi nilai kekuatan penggerak, artinya perubahan pada subkriteria tersebut memiliki dampak yang tinggi terhadap perubahan subkriteria lain. Semakin tinggi nilai ketergantungan, artinya perubahan pada kriteria lain akan memberi dampak yang besar terhadap perubahan pada subkriteria tersebut. Selanjutnya, Interfactorial dominance matrix diplot ke dalam grafik sehingga setiap subkriteria dapat dibagi menjadi empat kluster:

- Kuadran I : Autonomous Cluster (weak dependence - weak driving)

- Kuadran II : Dependen Cluster (strong dependence - weak driving)

- Kuadran III : Linkage Cluster (strong dependence - strong driving)

- Kuadran IV : Independen Cluster (weak dependence - strong driving)

\subsection{Konstruksi Model ANP}

Kriteria dan sub kriteria yang paling penting (prioritas) berdasarkan hasil analisis DDPA yang akan dikaji lebih lanjut. Hal ini dikarenakan sifat pada subkriteria tersebut yang memiliki ketergantungan yang besar dan kekuatan penggerak tinggi. Oleh karena itu, pemanfaatan elemen-elemen tersebut diharapkan tujuan dari kajian penelitian ini dapat tercapai. Konstruksi model jaringan dibuat dengan bantuan Super Decision Software.

\subsection{Penilaian Perbandingan Berpasangan}

Penilaian perbandingan berpasangan menggunakan kuesioner dengan skala Saaty (1-9). ANP menggeneralisasikan proses perbandingan berpasangan untuk menilai setiap komponen dengan memasukkan prioritas kriteria dan alternatif(Beyzanur $d k k, 2018)$. Kuesioner dari setiap responden ini akan

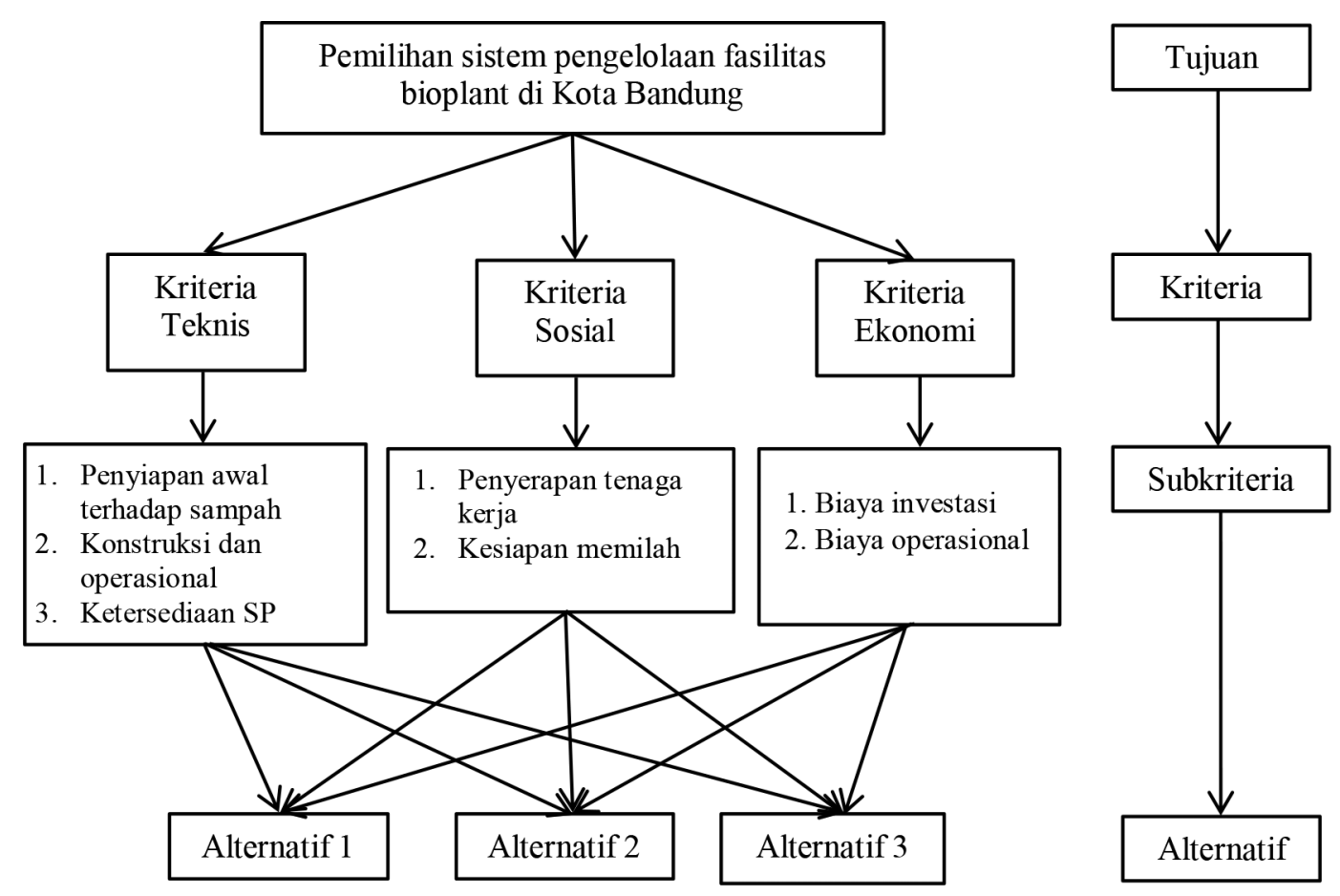

Gambar 3. Hirarki untuk penilaian perbandingan berpasangan

Tabel 4. Bobot dan consistency ratio setiap kriteria dari setiap kelompok responden

\begin{tabular}{lcccccccc}
\hline \multirow{2}{*}{ Kriteria } & \multicolumn{2}{c}{ Pemerintah } & \multicolumn{2}{c}{ Masyarakat } & \multicolumn{2}{c}{ Akademisi } & \multicolumn{2}{c}{ Pengelola } \\
\cline { 2 - 8 } & Bobot & CR & Bobot & CR & Bobot & CR & Bobot & CR \\
\hline Teknis & 0,1061 & & 0,1103 & & 0,1976 & & 0,0904 & \\
Sosial & 0,6333 & $4,77 \%$ & 0,5438 & $5,9 \%$ & 0,4905 & $5,2 \%$ & 0,5559 & $6,1 \%$ \\
Ekonomi & 0,2604 & & 0,3460 & & 0,3119 & & 0,3537 & \\
\hline
\end{tabular}




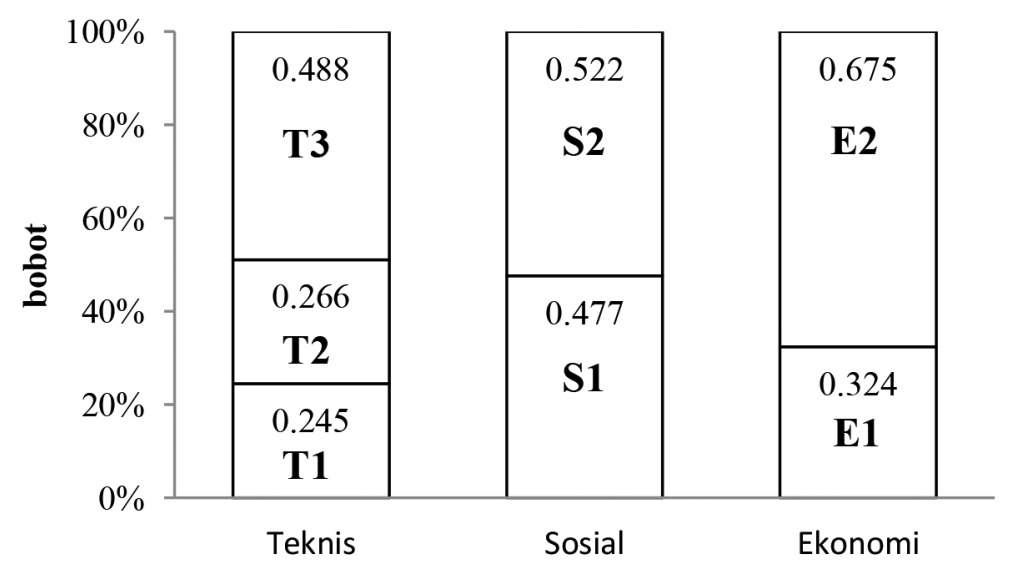

Gambar 4. Penilaian bobot lokal subkriteria

diuji konsistensi. Jawaban yang tidak konsisten akan direvisi. Hasil dari kuesioner perbandingan berpasangan dianalisis dengan Super Decision Software untuk memperoleh bobot kriteria dan sintesa alternatif pengelolaan fasilitas bioplant.

\section{Hasil dan Pembahasan}

\subsection{Evaluasi Kondisi Eksisting Fasilitas Bioplant}

Fasilitas bioplant untuk mengolah sampah organik telah dipasang di beberapa daerah di Kota Bandung, dimana resume kondisi di 4 lokasi diantaranya dapat dilihat pada Tabel 1.

Di seluruh fasilitas bioplant yang diobservasi tersedia wadah sampah organik yang sudah terpilah sehingga memudahkan pengelola dalam memasukan umpan tersebut ke biodigester. Jumlah sampah organik sebagai umpan lebih sedikit daripada kapasitasnya. Berdasarkan hasil wawancara, semua pengelola bioplant merasa keberatan memilah sampah untuk umpan biodigester karena membutuhkan waktu lama dan kekurangan pekerja. Selain itu, belum adanya pelatihan yang memadai bagi pengelola bioplant, tidak tersedianya biaya operasional dan perawatan membuat operasional bioplant seringkali terhambat.

Penggunaan biogas masih sebatas kebutuhan internal karena jumlahnya yang tidak mencukupi dan tidak ada sarana prasarana yang menunjang penggunaan biogas untuk keperluan eksternal. Di beberapa fasilitas, cairan direncanakan untuk dijual namun sangat sedikit yang bersedia membeli sehingga digratiskan. Masyarakat merasa keberatan dengan bau yang tidak sedap dan belum meyakini kemampuan cairan tersebut dalam menggemburkan tanah.

\subsection{Penentuan Kriteria, Subkriteria dan Alternatif}

Di awal penelitian, diusulkan 4 kriteria, yaitu: Teknis, Lingkungan, Sosial dan Ekonomi, dengan total subkriteria sebanyak 30 subkriteria dari keempat kriteria tersebut. Dari hasil penilaian stakeholder, hanya tersisa 16 subkriteria yang dianggap penting dari keempat kriteria, yang selanjutnya dianalisis lebih lanjut. Keempat kriteria dengan masing-masing subkriterianya dapat dilihat pada Tabel 2 .

Terdapat 3 alternatif pengelolaan bioplant yang

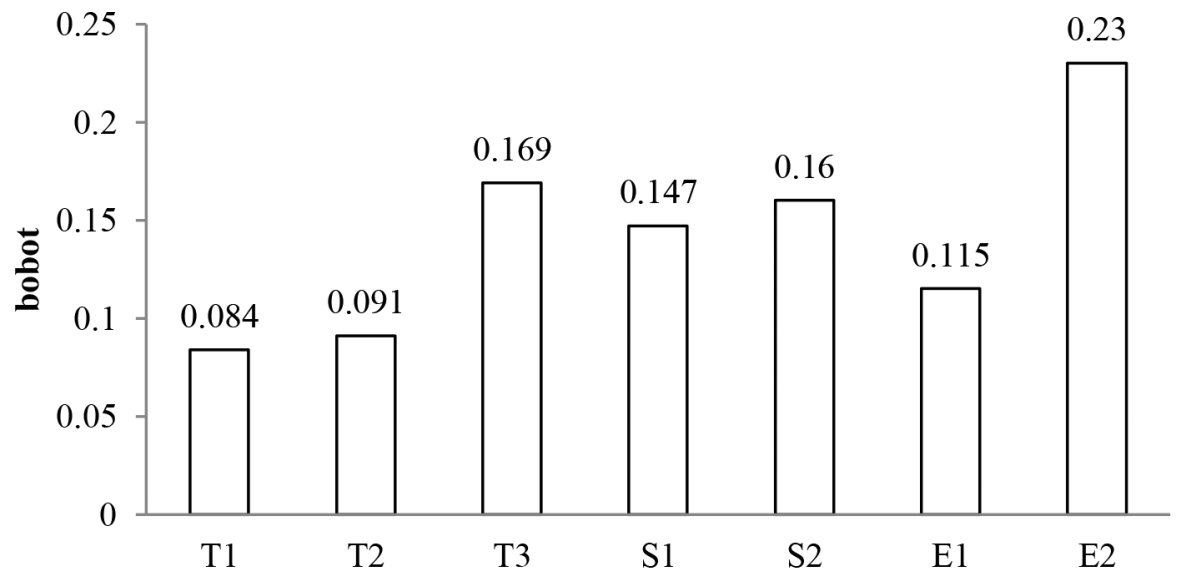

Gambar 5. Penilaian bobot global subkriteria 
diusulkan dan telah dinyatakan layak oleh stakeholder untuk diaplikasikan, dengan mempertimbangkan variasi dalam penanganan sampah di sumber, pengumpulan sampah, penanganan sampah di fasilitas bioplant, dan penggunaan produknya. Secara skematis, ketiga alternatif yang dimaksud dapat dilihat pada Gambar 1.

Pada Alternatif 1 sampah organik sebagai umpan di biodigester dipilah disumber oleh penghasil sampah lalu dikumpulkan oleh petugas. Karena sampah sudah terpilah, tidak dilakukan pemilahan sampah di fasilitas bioplant agar lebih efektif. Produk berupa biogas dan cairan digunakan untuk keperluan internal dan eksternal. Sistem implementasi Alternatif 2 hampir mirip dengan Alternatif 1 namun pengumpulan sampah dilakukan oleh penghasil sampah dan terdapat bank sampah di fasilitas bioplant tersebut. Adanya bank sampah diharapkan dapat meningkatkan peran serta masyarakat dalam menyediakan sampah organik rumah tangga sebagai umpan untuk biodigester. Pada Alternatif 3, tidak dilakukan pemilahan sampah di sumber, tetapi sampah tercampur dikumpulkan oleh petugas dan dilakukan pemilahan oleh petugas di fasilitas bioplant.

\subsection{Penentuan Hubungan Keterkaitan Antar Subkriteria}

Dari penilaian 31 responden, didapatkan Tabel hubungan ketergantungan antar kriteria (interfactorial dominance matrix) yang dapat dilihat pada Tabel 3 . Nilai kekuatan penggerak (driving power) didapatkan dari penjumlahan nilai pada baris di setiap subkriteria, yaitu nilai pada kolom paling kanan dari Tabel interfactorial dominance matrix. Sedangkan, nilai ketergantungan (dependence power) didapatkan dari penjumlahan nilai pada kolom di setiap subkriteria, yaitu pada baris paling bawah dari Tabel interfactorial dominance matrix. Subkriteria yang memiliki nilai kekuatan penggerak paling tinggi adalah Kesiapan masyarakat untuk memilah (S2, dengan nilai 11). Sedangkan subkriteria dengan nilai ketergantungan terbesar adalah Konstruksi dan operasional (T1), Ketersediaan sarana dan prasarana (T3), dan Biaya investasi (E1), dengan memiliki nilai yang sama yaitu sebesar 9.

Selanjutnya, nilai dari Interfactorial dominance matrix diplot ke dalam grafik sehingga didapatkan pemetaan keseluruhan subkriteria terhadap keempat kuadran yang didasarkan atas nilai kekuatan penggerak dan nilai ketergantungan (Gambar 2). Koordinat $\mathrm{x}$ pada grafik merupakan nilai kekuatan penggerak, sedangkan absis y merupakan nilai ketergantungan. Subkriteria dengan kekuatan penggerak paling besar adalah Kesiapan masyarakat untuk memilah sampah (S2) yang berada pada cluster linkage dengan titik koordinat x,y $(7,11)$. Subkriteria lain yang berada dalam cluster linkage adalah Penyiapan awal terhadap sampah (T1), Konstruksi dan operasional (T2), Penyerapan tenaga kerja (S1), Kesiapan masyarakat untuk memilah (S2), Ketersediaan sarana prasarana (T3), Biaya investasi (E1), dan Biaya operasional (E2). Analisis DDPA menunjukkan terdapat 25 inner dependence (keterikatan dalam satu kriteria) dan 52 outer dependence (keterkaitan antar kriteria).

Subkriteria pada cluster linkage memiliki kekuatan penggerak dan keterpengaruhan yang tinggi sehingga setiap tindakan terhadap subkriteria tersebut akan memberikan dampak terhadap subkriteria lainnya dan umpan balik pengaruhnya bisa memperbesar atau menimbulkan dampak yang baru. Oleh karena itu, subkriteria pada cluster ini dikaji dan digunakan sebagai dasar penyusunan model jaringan Analytic

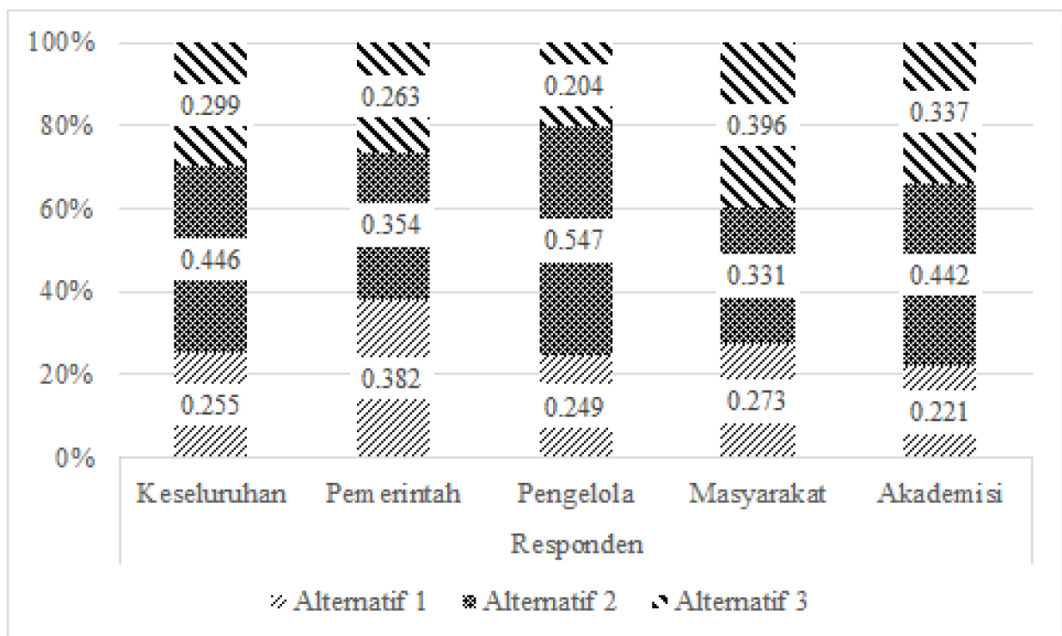

Gambar 6. Hasil penilaian alternatif sistem pengelolaan fasilitas bioplant secara agregat dan berdasarkan responden 


\section{Network Process (ANP).}

\subsection{Konstruksi Model ANP}

Setelah dilakukan analisis dependent and driving power, didapatkan tujuh subkriteria dari 3 kriteria yang paling mempengaruhi implementasi pengelolaan fasilitas bioplant di Kota Bandung. Kriteria Lingkungan dan semua subkriteria didalam kriteria Lingkungan tereliminasi karena dianggap tidak penting berdasarkan penilaian responden. Dari total 16 subkriteria yang dinilai dengan DDPA, hanya tersisa tujuh subkriteria terpilih yang masuk dalam susunan hierarki yang akan dilakukan penilaian perbandingan berpasangannya, sedangkan 9 subkriteria lain tidak dipakai lagi dalam analisis selanjutnya. Susunan hierarki dari kriteria, subkriteria, dan alternatif yang dihasilkan dapat dilihat pada Gambar 3.

\subsection{Penilaian Perbandingan Berpasangan \\ 3.5.1 Penilaian Bobot Kriteria}

Penilaian seluruh stakeholder menunjukkan trend yang sama, yaitu kriteria yang menjadi prioritas utama dalam pengelolaan fasilitas bioplant adalah kriteria sosial karena memiliki bobot paling tinggi, lalu kriteria ekonomi dan kriteria teknis. Nilai consistency ratio (CR) yang kurang dari 10\%, yaitu 4,77\%, 5,2\% dan $6,1 \%$ menunjukan bahwa perhitungan bobot konsisten dan dapat diterima (Tabel 4).

\subsubsection{Penilaian Bobot Subkriteria}

Untuk mengetahui subkriteria yang dianggap paling penting, dilakukan perhitungan nilai limiting dinormalisasi secara lokal dan global. Normalisasi lokal dilakukan terhadap subkriteria dalam satu kriteria, sedangkan normalisasi global dilakukan terhadap seluruh subkriteria. Hasil perhitungan yang sudah dinormalisasi secara lokal dan global dapat dilihat pada Gambar 4 dan Gambar 5.

Terdapat perbedaan hasil penilaian perbandingan berpasangan dengan hasil analisis DDPA. Berdasarkan analisis DDPA, subkriteria pada kriteria teknis yang memiliki nilai kekuatan penggerak dan ketergantungan paling tinggi adalah konstruksi dan operasional, lalu diikuti oleh ketersediaan sarana dan prasarana, lalu penyiapan awal terhadap sampah. Sedangkan hasil perbandingan berpasangan menunjukan bahwa subkriteria yang paling tinggi adalah ketersediaan sarana prasarana, penyiapan awal terhadap sampah, lalu konstruksi dan operasional. Subkriteria pada kriteria ekonomi yang lebih penting berdasarkan analisis perbandingan berpasangan adalah biaya operasional lalu biaya investasi. Berdasarkan analisis DDPA, biaya operasional memiliki kekuatan penggerak lebih tinggi sedangkan biaya investasi memiliki ketergantungan lebih tinggi. Pada analisis DDPA maupun analisis perbandingan berpasangan ANP, subkriteria kesiapan masyarakat untuk memilah memiliki tingkat kepentingan, kekuatan penggerak dan ketergantungan paling tinggi dibandingkan subkriteria penyerapan tenaga kerja.

Penilaian dengan DDPA menghasilkan subkriteria yang memiliki nilai kekuatan penggerak dan ketergantungan yang lebih besar daripada subkriteria lainnya. Sedangkan penilaian berpasangan menghasilkan subkriteria mana yang dianggap lebih penting daripada subkriteria lainnya dalam memilih sistem pengelolaan fasilitas bioplant.

Berdasarkan nilai normalisasi global, terlihat 3 subkriteria yang paling mempengaruhi, yaitu: biaya operasional (bobot 0,230) dari kriteria ekonomi, lalu ketersediaan sarana prasarana $(0,169)$ dari kriteria teknis, dan kesiapan masyarakat untuk memilah sampah $(0,160)$. Jika dibandingkan dengan evaluasi kondisi eksisting, ketiga hal tersebut berhubungan dengan faktor yang mempengaruhi keberlanjutan fasilitas bioplant.

\subsubsection{Penilaian Alternatif}

Secara keseluruhan responden lebih memilih Alternatif 2 sebagai sistem pengelolaan bioplant yang paling baik untuk diaplikasikan di Kota Bandung. Prioritas berikutnya adalah Alternatif 3, dan prioritas terendah adalah Alternatif 1. Urutan prioritas yang sama didapat dari penilaian responden akademisi. Urutan prioritas yang berbeda dihasilkan dari penilaian responden yang lain, dengan prioritas tertinggi berturut-turut adalah Alternatif 1 , Alternatif 2, dan Alternatif 3 untuk masing-masing responden pemerintah, pengelola dan masyarakat. Perbedaan penilaian ini dipengaruhi oleh latar belakang dan persepsi responden terhadap keberadaan suatu fasilitas bioplant.

Responden yang menempatkan Alternatif 1 sebagai prioritas tertinggi menilai pemilahan sampah mulai di sumber oleh penghasil sampah merupakan faktor penentu dalam keberlanjutan suatu fasilitas bioplant. Alternatif 2 dianggap sebagai alternatif yang lebih banyak menghasilkan pemasukan bagi fasilitas bioplant karena sampah anorganiknya juga dimanfaatkan dalam wadah bank sampah. Alternatif 3 yang memfasilitasi sampah tercampur untuk dipilah di fasilitas bioplant lebih dipilih oleh responden masyarakat. Hal ini menunjukkan bahwa masyarakat masih belum mau melakukan pemilahan sampah dan masih berharap keterlibatan petugas dalam penanganan sampah yang dihasilkannya. Hasil 
lengkap penilaian alternatif yang dihasilkan secara keseluruhan responden dan masing-masing kelompok responden dapat dilihat pada Gambar 6 berikut.

\section{Kesimpulan}

Keberlanjutan suatu fasilitas penanganan sampah, termasuk fasilitas bioplant yang ada di Kota Bandung, dipengaruhi oleh berbagai macam kriteria dan pola pengelolaannya. Penelitian ini mengembangkan analisis multikriteria yang meliputi kriteria Teknis, Lingkungan, Sosial dan Ekonomi dengan total 30 subkriteria dari keempat kriteria tersebut. Dari hasil penilaian awal stakeholder, hanya tersisa 16 subkriteria yang dianggap penting dari keempat kriteria, yang selanjutnya dianalisis lebih lanjut menggunakan metode Analytic Network Process (ANP).

Dari penilaian 31 responden melalui prosedur Dependence and Driving Power Analytic (DDPA), didapatkan bahwa tidak ada subkriteria dalam kriteria Lingkungan yang masuk dalam cluster linkage yang memiliki nilai kekuatan penggerak (driving power) dan ketergantungan (dependent) tinggi. Subkriteria yang masuk dalam cluster linkage adalah Penyiapan awal terhadap sampah, Konstruksi dan operasional, Ketersediaan sarana prasarana (untuk kriteria Teknik), Penyerapan tenaga kerja, Kesiapan masyarakat untuk memilah (untuk kriteria Sosial), dan Biaya investasi, dan Biaya operasional (untuk kriteria Ekonomi).

Hasil perbandingan berpasangan terhadap kriteria dan subkriteria hasil DDPA menunjukkan kriteria Sosial dan subkriteria Biaya operasional menjadi prioritas dari seluruh responden. Dari 3 alternatif sistem pengelolaan bioplant yang diajukan, setiap kelompok responden memiliki urutan yang berbeda. Akan tetapi, dari penilaian agregat semua reponden didapatkan bahwa Alternatif 2, dimana penghasil sampah melakukan pemilahan sampah dilakukan di sumber dan pengumpulan ke fasilitas bioplant secara mandiri dan adanya bank sampah yang dapat memaksimalkan potensi sampah anorganiknya.

\section{Daftar Pustaka}

Aragones-Beltran, P., Pastor-Ferrando, J.P., GarciaGarcia, F., Pascual-Agullo, A., 2010. An analytic network process approach for sitting a municipal solid waste plant in the Metropolitan Area of Valencia (Spain). Journal of Environmental Management. 91(5): 1071-1086. 10.1016/j. jenvman.2009.12.007

Arikan, E., Simsit-Kelender, Z.T., Vayvay, O., 2017. Solid waste disposal methodology selection using multi-criteria decision making methods and an application in Turkey. Journal of
Cleaner Production. 142(1):403-412. https://doi. org/10.1016/j.jclepro.2015.10.054

Aziz, A., Ihsan, T., Permadani, A.S., 2019. Skenario pengembangan system pengelolaan sampah Kabupaten Pasaman Barat dengan pendekatan skala pengolahan sampah di tingkat kawasan dan kota. Jurnal Serambi Engineering. 6:444-450.

Neyzanur, C.E., Zaim, S., Demirel, O.F., Aydin, Z., Delen, D., 2018. An ANP and fuzzy TOPSIS-based SWOT analysis for Turkey's energy planning. Renewable and Sustainable Energy Reviews. 82(1):1538-1550. https://doi.org/10.1016/j. rser.2017.06.095

Bottero, M., Comino, E., Riggio, V., 2011. Application of the analytic hierarchy process and the analytic network process for the assessment of different wastewater treatment systems. Environmental Modelling and Software. 26(10): 1211-1224. https://doi.org/10.1016/j.envsoft.2011.04.002

Coban, A., Ertis, I.F., Cavdaroglu, N.A., 2018. Municipal solid waste management via multicriteria decision making methods: A case study in Istanbul, Turkey. Journal of Cleaner Production. 180:159-167. https://doi.org/10.1016/j. jclepro.2018.01.130

Gitinavard, H., Mousavi S.M., Vahdani, B., 2017. Soft computing based on hierarchical evaluation approach and criteria interdependencies for energy decision-making problems: A case study. Energy. 118:556-577. https://doi.org/10.1016/j. energy.2016.10.070

Helmy, M., Laksono, T.B., Gardera, D., 2006. 3R implementation in Indonesia. Proceeding of Senior Official Meeting on 3R Inittiative. JIC. Tokyo, Japan.

Jingura, R.M., Matengaifa, R., 2009. Optimization of biogas production by anaerobic digestion for sustainable energy development in Zimbabwe. Renewable and Sustainable Energy Reviews. 13(5):1116-1120. https://doi.org/10.1016/j. rser.2007.06.015

Kasirian, N.M., Yusuff, R.M., Ismail, M.Y., 2010. Application of AHP and ANP in supplier selection process - A case in an automotive company. International Journal of Management Science. 5(2):125-135

Khan, S., Faisal, M.N., 2008. An analytic network process model for municipal solid waste disposal options. Waste Management. 28(9): 1500-1508. https://doi.org/10.1016/j.wasman.2007.06.015

Liao, C.H., Chiu, A.S.F., 2011. Evaluate municipal solid waste management problems using hierarchical framework. Procedia-Social and 
Behavioral Sciences. 25: 353-362. https://doi. org/10.1016/j.sbspro.2011.10.554

Molinos-Senante, M., Gomez, T., Caballero, R., Hernandez-Sacho, F., Sala-Garrido, R., 2015. Assessment of wastewater treatment alternatives for small communities: An analytic network process approach. Science of the Total Environment. 532:676-687. https://doi. org/10.1016/j.scitotenv.2015.06.059
Nizar, M., Munir, E., Munawar, E., Irvan, 2017. Manajemen pengelolaan sampah kota berdasarkan konsep zero waste: Studi literatur. Jurnal Serambi Engineering. 1(2):93-102.

Tseng, M.L., 2009. Application of ANP and DEMATEL to evaluate the decision-making of municipal solid waste management in Metro Manila. Environmental Monitoring Assessment. 156(1):181-197. 10.1007/s10661-008-0477-1 